\title{
Career guidance and active labour market policies in the Republic of Armenia
}

\author{
Peter J. Robertson ${ }^{1}$ D Anahit Melkumyan ${ }^{2}$
}

Received: 27 January 2020 / Accepted: 27 September 2020 / Published online: 17 October 2020

(c) Springer Nature B.V. 2020

\begin{abstract}
This article provides an account of current public policy for career guidance in the Republic of Armenia. Brief background information is provided in terms of key geographical, political, social and economic facts about Armenia. Then, a more specific context is outlined with a brief overview of the education and skills system and of the labour market environment. Career guidance in Armenia needs to be understood in relation to recent public policy initiatives to introduce active labour market programmes. The scope of these programmes is outlined and a critique of current policy is provided. Finally, priorities for future development are considered.
\end{abstract}

Keywords Active labour market programmes - Career guidance · Labour market · Public policy $\cdot$ Republic of Armenia $\cdot$ Skills $\cdot$ Vocational education and training

\section{Resumé}

Orientation professionnelle et politiques actives du marché du travail en République d'Arménie Cet article rend compte de la politique publique actuelle en matière d'orientation professionnelle dans la République d'Arménie. De brèves informations générales sont fournies en termes de faits-clé concernant l'Arménie d'un point de vue géographie, politique, social et économique. Ensuite, un contexte plus spécifique est décrit, avec un bref aperçu du système d'éducation et de compétences ainsi que du marché du travail. L'orientation professionnelle en Arménie doit être comprise en relation avec les récentes initiatives d'introductions de programmes de politique publique active du marché du travail. Le champ d'application de ces programmes est décrit et une critique de la politique actuelle est fournie. Finalement, les priorités pour le développement futur sont examinées.

\section{Peter J. Robertson}

p.robertson@napier.ac.uk

1 School of Applied Sciences, Edinburgh Napier University, Edinburgh, Scotland, UK

2 Armenia State University of Economics, Yerevan, Armenia 


\section{Zusammenfassung}

Laufbahnberatung und aktive Arbeitsmarktpolitik in der Republik Armenien Dieser Artikel gibt einen Überblick über die gegenwärtige öffentliche Politik zur Laufbahnberatung in der Republik Armenien. Es werden kurze Hintergrundinformationen in Bezug auf die wichtigsten geographischen, politischen, sozialen und wirtschaftlichen Fakten über Armenien gegeben. Dann wird ein spezifischerer Kontext mit einem kurzen Überblick über das Bildungs- und Qualifikationssystem und das Arbeitsmarktumfeld skizziert. Die Laufbahnberatung in Armenien muss im Zusammenhang mit den jüngsten politischen Initiativen zur Einführung aktiver Arbeitsmarktprogramme verstanden werden. Der Umfang dieser Programme wird umrissen, und es wird eine Kritik an der gegenwärtigen Politik geübt. Schließlich werden Prioritäten für die zukünftige Entwicklung vorgeschlagen.

\section{Resumen}

Orientación profesional y políticas activas del mercado laboral en la República de Armenia Este analiza las políticas públicas actuales de orientación profesional en la República de Armenia. Se exponen una breve información sobre los antecedentes, en términos de hechos geográficos, políticos, sociales y económicos clave sobre Armenia. A continuación se describe un contexto más específico con una breve revisión del contexto del sistema educativo y de competencias así como del mercado laboral. La orientación profesional en Armenia debe entenderse en relación con las recientes iniciativas de políticas públicas para introducir planes activos planes activos de empleo. Se describe el alcance de estos programas y se ofrece una visión crítica de la política actual. Finalmente, se consideran prioridades para el desarrollo futuro.

\section{Introduction}

The Republic of Armenia lies in the Southern Caucasus region. It is a landlocked country bordering with Turkey, Georgia, Azerbaijan, and Iran. The borders with Turkey and Azerbaijan are currently closed due to long-standing political disputes. It has a democratic government and is a predominantly Christian country, with the ancient Armenian church representing one defining feature of cultural identity. For these reasons Armenia leans culturally and historically towards Europe, whilst being located within what is now a predominantly Islamic region. Along with joining the Eurasian Economic Union, comprising former Soviet states, simultaneously Armenia's relations with the European Union are developing. The EU-Armenia Comprehensive and Enhanced Partnership Agreement (CEPA) was signed in 2017, with areas of joint cooperation including education, business, employment, and human rights. Armenia's human rights record is better than the norms for former Soviet republics (UNESCO, 2008), and there is a commitment to good governance (World Bank, 2019), with recent improvements in tackling corruption.

Approximately three million people live in Armenia, with ethnic or national minorities representing less than $2 \%$ of the population (Republic of Armenia, 2019a). The country is well connected internationally through an extensive and 
prosperous Armenian diaspora. The Armenian language, with its unique writing script, represents another defining cultural feature. Russian and English are widespread second languages.

Armenia is an upper middle-income nation (World Bank, 2012). Important and priority industries include information and communication technologies, tourism, manufacturing and agriculture. The economy is sensitive to the state of economic growth in Russia (European Training Foundation [ETF], 2016). Poverty reduction represents a major long-term economic policy objective. The Armenia Development Strategy (2014-2025) identifies employment and human capital development as two of the four priority goals, and explicitly recognises the importance of youth employment for the future welfare of the nation (ETF, 2019).

The aim of this article is to evaluate public policy for career guidance in Armenia, and to place it in a wider context, with particular reference to active labour market programmes (ALMPs). As McCarthy and Borbély-Pecze (2020) point out, career guidance policy tends to be peripheral to policymaking in relation to education, employment and social inclusion. They also note the dearth of studies of policy formation and implementation. By describing the emerging Armenian approach, we hope to provide a case study which locates career guidance policy in the environmental influences that shape its evolution. The article will first outline some key contextual issues: the education and skills environment, and the nature of the labour market. It will then provide an account of the emergence of active labour market interventions in Armenia, and explore public policy for career guidance. A critique will be provided of these developments, together with a consideration of priorities for the future.

\section{An overview of education and skills}

The education sector comprises pre-school institutions; general schools (primary, middle, basic, senior, gymnasium, secondary); preliminary and middle vocational education institutions; and higher and post-graduate educational institutions. Public expenditure on education is relatively low in comparison to European Union benchmarks, and in consequence there is a significant private education sector, but also a recognition that greater state investment will be needed (ETF, 2019). An eight level National Qualification Framework was adopted in 2011 and updated in 2016 (ETF, 2018b).

The higher education system in 2018 included 56 state and private higher educational establishments. It is regulated by the Law on Education of 1999, and the Law on Higher and Post-Graduate Professional Education, adopted in 2004 (European Union, 2017). In 2005 Armenia joined the Bologna Process and began participation in the European Higher Education Area (EHEA). New draft legislation on higher education and science is currently under consideration in the parliament. State policy objectives for higher education are directed towards the development and quality assurance, the promotion of international educational and scientific cooperation, and the introduction of a national qualifications framework that is consistent with European standards. The reforms are intended to make the higher education system 
more compatible with international norms, to strengthen quality assurance mechanisms, and increase staff and students' mobility. The National Centre for Professional Education Quality Assurance (ANQA, 2018) introduced a system of accreditation of higher education institutions. More than 20 state and private universities have adopted internal QA systems.

The vocational education and training (VET) system in Armenia is relatively small in comparison to the higher education sector (ETF, 2019). It includes two levels: 'preliminary' and 'middle'. In 2017 preliminary VET was provided in 44 colleges; and middle vocational education in 93 colleges. A comparatively low proportion of students attend VET colleges-nearly $10 \%$ of the total number of students enrolled in general education schools (State Statistical Committee of the Republic of Armenia, 2018). It is anticipated that some VET colleges will be transformed into regional centres of excellence thus attracting more students (ETF, 2019). Since 2003, the European Union has been the main donor for VET reforms in Armenia, supporting the establishment of a regional network of VET institutions, staff training, and development of training standards (ETF, 2018a). Since 2015, articulation agreements between vocational education institutions and universities allow academically strong students to progress into higher education.

\section{An overview of the labour market}

There has been considerable economic change in Armenia in recent decades, as labour market indicators demonstrate. Between 1995 and 2017, the employment rate decreased substantially from 71 to $50 \%$. Similarly, the labour force participation rate (LFPR) decreased from 76 to 61\% (State Statistical Committee of the Republic of Armenia, 2018). After 2013, the deterioration in the labour market indicators is particularly marked. There are a number of causal factors. There have been both demographic changes and economic changes. Post-independence in 1992, the transition from a Soviet centralized state-controlled economy towards a free market has been an important structural change (ILO, 2011). Insufficient investment in the economy targeted on the creation of new jobs was another important factor. A high proportion of workers-approximately half the workforce-are in informal employment, predominantly in agriculture. The rates of economic inactivity, unemployment, informal employment, low pay, and vulnerable employment are particularly high among young people and among workers in rural areas (ILO, 2011; Save the Children, 2018; Serrière, 2014). Entry to the labour market is possible at age 16 years. Limited work is permitted for those aged 14-16, compatible with their health, safety and education. Youth unemployment is often of long-term duration (ILO, 2016).

There are also qualitative and quantitative mismatches between labour demand and supply, including skill shortages. Data from the employment centres demonstrates that some vacancies remain unfilled for long periods because of a lack of suitably qualified workers (State Statistical Committee of the Republic of Armenia, 2018). This issue may be resolved through further development of vocational education including the creation of centres of excellence that may attract young people. An over-supply of graduates seeking high status professions is also a problem, and 
Table 1 Labour market public expenditure in the Republic of Armenia in 1995-2016 as a percentage of Gross Domestic Product (GDP)

\begin{tabular}{llll}
\hline & $1995(\%)$ & $2001(\%)$ & $2016(\%)$ \\
\hline Active programmes & 0 & 0.03 & 0.05 \\
Passive programmes & 0.13 & 0.03 & 0 \\
Total expenditure & 0.13 & 0.06 & 0.05 \\
\hline
\end{tabular}

Source Employment state agency/Statistical committee (Republic of Armenia, 2019b)

its corollary is an undersupply in other important vocational areas: 'Armenian youth are highly educated, but shun vocational education' (Serrière, 2014, p. 1). Being over-qualified is more common that being under-qualified among young workers (ILO, 2016).

Public sector work is attractive due to its greater security but the sector cannot absorb all the potential entrants it attracts (ILO, 2016). Females experience disadvantages in the transition from education to work, largely due to domestic responsibilities, and have more restricted vocational choices than males, tending to be concentrated in a narrow range of acceptable service sector occupations (Save the Children, 2018; Serrière, 2014).

In spite of these challenges, labour market policy in Armenia has been positively evaluated by international organizations. According to the Global Competitiveness Report (Schwab, 2019), Armenia was ranked 32nd among 141 countries against the indicator for labour market conditions, a measure which included human resources practices, flexibility of wage determination, and industrial relations. These are in addition to active labour market policies, to which we now turn our attention.

\section{Active labour market policies}

In 1991 the independent Republic of Armenia was proclaimed, and employment legislation created the State Employment Agency. This is a public employment service (PES) with a regional structure. In 1995-2000 the limited budget resources available were mainly directed on the implementation of passive labour market policy in the form of welfare benefits for registered unemployed people of working age. Recent legislation (Republic of Armenia, 2013) led to the introduction of a new model from 2014 which marked a move away from reliance on passive policies, towards adoption of active labour market policies.

The structure of labour market public expenditure is represented in the Table 1. It shows the dramatic shift from passive to active policy measures. ALMPs were prevailing by 2016, making up almost $0.05 \%$ of Gross Domestic Product (GDP). All unemployment benefits for the working age population have been discontinued.

A number of active labour market programmes (ALMPs) were introduced, including:

- Vocational training programmes for job seekers who are unemployed. This encompasses other key target groups including employees notified of the 
termination of their employment contract, and women registered with an employment agency after a three-year period of maternity leave. The programmes develop skills which are in demand in the labour market, and support placement into work.

- An entrepreneurship programme to support unemployed people to become self-employed. This facilitates the creation of new work opportunities. A national centre provides business support to small and medium sized enterprises.

- A professional work experience programme to support young unemployed people who are new entrants to the labour market. This is limited to those within five years of graduation.

- A programme of support for young mothers in the form of on-the-job vocational training.

- A state subsidy for child care for young mothers. This covers half the costs of child care, but is capped to ensure the monthly minimum wage is not exceeded.

- Financial support to employers recruiting unemployed people who are disadvantaged in a competitive labour market (for example, disabled workers). This includes partial wage subsidies, and lump sum payments for training and skills development.

- Support to overcome regional geographical barriers in the form of a subsidy for a journey from home to work greater than $30 \mathrm{kms}$.

- A subsidy for agriculture to promote seasonal employment.

- Incentives for private employment agencies to assist those unemployed for more than 3 months, payable on placement into work.

A variety of additional measures are available including the use of job fairs, job clubs, and targeted support for attending job interviews. Used in combination with human capital development initiatives, ALMPs seek to address issues of labour supply. Armenia also engages in the stimulation of labour demand through financial, tax, and investment policy measures. This approach is consistent with the European Employment Strategy (European Union, 2019). In particular, a programme of public works was successful in generating temporary jobs and alleviating poverty over the last decade.

A key barrier to the success of this suite of programmes is the low level of participation. Just 5\% of the registered unemployed are engaged in these programmes; only $10 \%$ of the unemployed sought assistance from the State Employment Agency (ETF, 2016). Engagement is particularly weak among young people (Save the Children, 2018). To some extent this may reflect strong targeting of services on the most disadvantaged groups. There are two further factors hindering the effective support for economically inactive people to enter work or vocational training. There is insufficient information on the occupational structure of the labour market, and where demand for workers can be found; and there are skill gaps and skill shortages in the supply of labour. Hence, there is a clear economic case for career guidance services. 


\section{Public policy for career guidance}

Reforms of career guidance policy and provision were initiated in 2012 when the Professional Guidance System Development Concept and the associated implementation programme were adopted by the Government (Republic of Armenia, 2012). In 2015, the EU programme 'Better qualifications for better jobs' was launched focused on the improvement of labour market efficiency including guidance services, and the employability of the workforce in the agricultural sector. In 2018 'EU4Youth' and 'EU4Innovation' initiated programmes were also focused on skills development and reducing mismatch between the skills of young people and labour market needs. Recently, the European Training Foundation has been supporting the development of career guidance policy in Armenia (ETF, 2018a). The reforms can be can be understood in terms of institutions at three levels: policy elaboration, technical support and training, and service providers.

\section{Policy level}

Responsibility for policy development is shared between the Ministry of Labour and Social Issues, and the Ministry of Education, Science, Culture and Sport. The creation of a professional guidance system was a joint project between these ministries, facilitating implementation in both the education and employment systems.

\section{Technical support}

The development of skills for career guidance practitioners has been led by the Professional Guidance and Capacity Building Centre ${ }^{1}$ (Ministry of Labour and Social Issues, undated). The Centre develops methods for career guidance that are differentiated for different institutional settings and service user groups. The National Institute for Education cooperates with the Centre in developing teaching materials for basic and vocational skills development, for career education and personal development. The Centre provides training for practitioners, and develops occupational information. It is developing labour market intelligence and sharing its analysis of job vacancies. The Centre also supports career specialist websites, and conducts monitoring, liaison and marketing functions on behalf of the network (ETF, 2016). The work of the centre has been considered as a successful example of cooperation in vocational education between the Ministry of Labour and Social Issues and Ministry of Education and Science (ETF, 2018c).

\section{Service providers}

According to the concept, the career guidance system includes general secondary education, professional education, and institutions supporting career issues as

\footnotetext{
1 This name is translated as the 'Methodological Centre for Professional Orientation' by the ETF (2016).
} 
integrated social services (ISS) and employment centres (EC). These are understood to be all part of one integrated chain of provision, whilst a clear distinction could be made between provision within the education system and outside of it. With the exception of schools, most elements of the system have embedded career centres into existing structures.

\section{Secondary schools}

The initial component of career guidance is general secondary education where the reforms started. In 2013-2018, 400 schools from all the regions of Armenia were involved in career guidance system - this represents one-third of the general education schools of the Republic. More than 800 teachers were trained to engage in careers work. The staff providing individual career guidance in secondary schools are mostly social pedagogues or psychologists. Across the regions, a revision of the curriculum to support science, technology, engineering and mathematics (STEM) is in progress, with the adoption of new educational technologies. Professional orientation clubs have been established at schools across the country, where lectures are delivered once a week on occupations and labour market demand. These lectures are seen by school leadership as an efficient way to address student career planning needs.

\section{Vocational colleges}

Since 2013 career guidance centres have been introduced within 22 VET colleges. This development has been supported by close cooperation with the Professional Guidance and Capacity Building Centre. During 2013-2018 more than 140 specialists from all the colleges in the capital and regions were trained to offer career support. Also, state education standards are developing in VET, and entrepreneurship will be included in all the vocational education programmes. A regional network of VET institutions was established, with 17 colleges turned into VET centres of excellence. Students of the vocational colleges are legally entitled to postpone their military service.

\section{Universities}

Career centres were also created at all the universities. They organize career workshops, provide counselling and offer internships. The specialists from 14 universities were trained based on the analysis of demanded skills and competencies. The main objective is supporting student employability, occupational choice, and development of entrepreneurship competencies, with a view to enabling graduates to compete in the labour market (European Union, 2017). Career centres in universities tend to prioritise co-ordination activities over counselling. There is currently no national framework of standards for careers work in the university sector, and this may limit their effectiveness. 


\section{Integrated social service (ISS) and employment centres (EC)}

These provide lifelong guidance. During 2013-2016 the model of professional career guidance services delivered via ISS and EC was implemented. Specialist practitioners from all the 51 regional EC were trained in counselling skills and support for employability. However, the responsible specialists often lack relevant professional qualifications (e.g. as a psychologist, social worker, or similar). The main task of the employment services is evaluating the job needs of the unemployed jobseekers, development of their skills, and strengthening motivation. ECs regularly implement surveys of labour demand which reveal some obstacles for filling vacancies, mostly related to the lack of demanded skills and work experience.

Labour force guidance is based on the employers' demand and labour market forecasting. It includes individual counselling and informing on job vacancies, training opportunities and employment support programs. In 2018, 25\% of those seeking work registered at the EC received professional counselling (Republic of Armenia, 2019b).

\section{Theoretical models of career guidance}

Different models of career guidance are delivered in EU neighbouring countries (ETF, 2011; Zelloth, 2009). These offer a basis for comparison, and from this perspective, the approach adopted in Armenia can be considered as a hybrid model. It adopts elements of (i) educational, (ii) person-centred, (iii) developmental, and (iv) matching/person-environment fit thinking, all within the context of an economic strategy. These are discussed briefly below.

(i) Within schools and vocational colleges, the approach is fundamentally pedagogical. It promotes transferable learning of career management skills. Careers work is integrated to the curriculum. This reflects well-established concepts of career education (e.g. Barnes et al., 2011).

(ii) A non-directive method of counselling is used mainly in the employment services of Armenia. This is considered as an appropriate approach to respond to social, moral and emotional issues (Kapunan, 1974). Rooted in person-centred counselling, this approach is humanistic, and intended to promote self-directed career planning. Unlike educational approaches, the non-directive counselling approach will tend to address current issues, rather than improve the ability of the individual to solve the problems in the future. Anticipated changes in counselling methods may include a shift from vocational decision-making to life-designing and career construction (Savickas et al., 2009).

(iii) Career centres provide services for the adult population outside of education and training institutions. This, combined with a differentiated approach for young people, demonstrates the influence of lifespan development models of careers in the tradition of Super (e.g. 1980), and an aspiration to life-long guidance services. 
(iv) The RIASEC model of vocational personalities and work environments (Holland, 1997) is perceived as an efficient structure allowing counsellors to distinguish and match attributes of six vocational personalities and work environments. This approach continues to be influential (e.g. Savickas, 2015), and is applied in Armenia.

Notwithstanding the adoption of these psycho-social and educational methods, the Armenian strategy is labour-market oriented. It is intended to be cost-effective and reach a wide range of service users. It has an economic rationale, and serves a wider economic development agenda.

As is the case in many countries, the COVID-19 pandemic has been a shaping influence on career guidance delivery models. Remote and online methods of delivery are currently in development, a process which goes hand in hand with a shift to online delivery of learning programmes. Arguably, globalization and the turn to online service delivery will foster new theoretical approaches to career counselling in the 21-st century (Savickas et al., 2009). Contemporary career theories emphasize the importance of socio-economic context, and aim to develop skills for lifelong learning, and the adaptability to cope with the challenge of uncertainty (Cohen-Scali et al., 2017).

\section{Discussion and critique}

In this section we will consider four perspectives from which to discuss and critique Armenian arrangements. Firstly, we will consider what can be learnt from benchmarking against international reviews. Secondly, we will consider assessments by international bodies of the Armenian education and employment systems. Thirdly, we will consider empirical evidence of guidance impact from Armenia. Finally, some comment will be offered on career guidance within a wider employment policy context.

\section{International policy benchmarks}

There are no international comparative studies of career guidance policy that have examined Armenia. Here we will explore three international reviews, which are progressively more relevant to the Armenian experience.

Sultana and Watts (2008) describe a study undertaken on behalf of the ETF of career guidance in ten Middle Eastern and North African (MENA) nations ${ }^{2}$. In spite of the geographical proximity of some of these nations, they are problematic as policy comparators for Armenia. Most are culturally Islamic, with strongly gendered and family driven occupational choices. They have a different (post-colonial)

\footnotetext{
${ }^{2}$ Eight countries in the review are described as Arab: Algeria, Egypt, Jordan, Lebanon, Morocco, Tunisia, Syria, plus the West Bank and Gaza Strip territories; two non-Arab nations were included: Israel and Turkey).
} 
history, and they have different educational and institutional traditions. That said, some broad-brush economic challenges found in this review are shared by Armenia. These include rural poverty, a large informal economy, emigration, and low levels of unemployment protection (which leads to public sector employment being seen as particularly attractive). The MENA analysis is usefully extended across the Mediterranean by Sultana $(2017 \mathrm{a}, \mathrm{b})$, who offers a perspective on provision that seeks an understanding of provision in terms of its own local culture, rejecting external (Northern European) frameworks of analysis. Key issues across the region with implications for career guidance included inequality, identity, informality, mobility, community, spirituality, and reflexivity.

A slightly better comparison group is offered by Watts and Fretwell (2004) who reported for the World Bank on developing and emerging economies by collating seven case studies. ${ }^{3}$ This review found policy thinking that has considerable resonance with the Armenian Government's position:

There are however signs of a more dynamic and proactive policy rationale emerging in middle-income countries, as is the case in developed countries. Career guidance is increasingly viewed as an integral part of a human resource development strategy designed to harness technological and economic change and enable the country to compete effectively in global markets (Watts \& Fretwell, 2004, p. ii).

Zelloth (2012) concurs that career guidance has been moving up the agenda for middle-income nations as part of wider strategic policymaking. It seems that Armenia is facing comparable policy development issues to other middle-income nations.

Perhaps the most interesting comparison comes from the study by the ETF of career guidance provision in nine EU neighbouring nations ${ }^{4}$ (Zelloth, 2009). This report suggests that demand for career guidance is growing, and the policy rationale for it is growing stronger. The inclusion of Georgia is of particular interest because it represents the closest available comparator to Armenia, in geographical, economic, historical, and cultural terms. Georgia faces similar issues of under-employment of graduates, and a big informal economy. But again, the policy comparison is imperfect. Georgia began experimenting with creating formal career guidance services around 2006/2007, but unlike Armenia it abolished both active and passive labour market measures at the same time, so the policy context was rather different. Georgia established a number of VET centres, with embedded career guidance practitioners. So (at the time of the study) the potential for development seemed to be around VET, in the absence of a public employment service.

The ETF report also highlighted a successful pilot project, drawing on international donor funding, to establish a Job Counselling and Referral Centre in 2007 in Tbilisi in Georgia. The two priority target groups for career guidance services

\footnotetext{
${ }^{3}$ The seven case studies were: Chile, the Philippines, Poland, Romania, Russia, South Africa and Turkey.

4 The nine countries were: Montenegro, Republic of Macedonia (now known as North Macedonia), Turkey, Albania, Ukraine, Georgia, Russia, Egypt, and Jordan.
} 
were returning migrants and potential emigrants. The centre also engaged with support activities such as labour market research to address a serious lack of information, capacity building, and training for VET staff. During 2000-2014 the ETF programmes in Georgia were targeted on support for the employment and training of migrants, and to reduce illegal migration (ETF, 2015). Among the most popular were entrepreneurship programmes and micro-credits for new businesses. As a result, improved institutional and legal frameworks for managing migration have been established. Migration is also a significant issue in Armenia (ILO, 2009).

Reflecting on the ETF review, Zelloth (2012) suggests that former Soviet nations may experience some tension between collectivist and individualist values, the former associated with the historical legacy of a communist state dependence and obedience, and the latter associated with empowerment, choice and responsibility inherent in transition to free market economies. There is little evidence that this a significant factor in Armenia, perhaps reflecting strong European leanings.

\section{International assessment of the Armenian education and employment interface}

These reforms were favourably reviewed by the EU and ETF monitoring commissions (ETF, 2016; European Commission, 2019). Specifically, the successful experience of the Professional Guidance and Capacity Building Centre is seen as a good practice: 'The work of the Centre is acknowledged as a successful example of cooperation in vocational education between the ministries of Labour and Education' (ETF, 2016, p10). It is seen as a model for introduction to the other CIS countries. The notion of a centre taking a lead on methods for career education and guidance makes possible a resource for psychological techniques, without developing a psychologically dominated profession. This is consistent with the OECD (2010) recommendation that career guidance should not be subsumed within psychological counselling, to facilitate the development of a distinctive career guidance professional identity. This allows for front line practitioners to be strongly connected to labour market information, the latter representing a critical but neglected aspect of guidance (Bimrose, forthcoming). Strong connection to the education system tends to present less of a problem, although guidance too strongly rooted in academic culture may lead to practitioners privileging academic over vocational qualifications (Watts, 2009), which could aggravate the existing status bias in young people's career choices in Armenia.

\section{Empirical evidence from Armenia}

There is some early evidence of the impact of the new models for guidance on young people's aspirations. A survey of educational guidance for high school students revealed that the majority intended to progress to tertiary education (Professional Guidance and Capacity Building Centre, 2010). Results of a second survey across 20 schools showed the career guidance positively affected future educational aspirations of pupils, as the overwhelming majority of them intended to continue professional education at the universities or vocational 
colleges (Professional Guidance and Capacity Building Centre, 2016). Participation in career guidance was also associated with a markedly lower level of intention to emigrate-at half the rate of non-participants. This is of interest because the emigration of young people from Armenia is at a level sufficient to affect the nation's demographic structure, and is seen as a loss of talent (Serrière, 2014; ETF, 2019).

\section{Career guidance in a wider employment policy context}

A close relationship between career services and state labour market interventions makes sense in terms of integrating provision, but is not unproblematic. Whilst career development functions in academic institutions generally have a distinctive identity, governments and international bodies tend to conflate career education and guidance with VET (Watts, 2009), or see it as little more than a supporting function or adjunct to VET policies. Few authors capture the complexity and nuance of the relationship between career guidance and VET; Zelloth (2012) is a notable exception. Similarly few authors address the relations between career guidance and ALMPs, with the notable exception of Moreno da Fonseca (2015), who notes a divergence in policy across Europe.

Sultana and Watts (2006) reviewed career guidance provision delivered by PES agencies in Europe, and found tensions firstly between the long-term focus of career guidance and the short-term pressures for rapid placement of unemployed people into work; and secondly between the person-centred, non-directive nature of career guidance and the role of the PES as gatekeepers to public resources. To date, these factors do not seem to have been important in Armenia, perhaps because the State Employment Agency is not involved in the policing of welfare benefit conditionality, and attracts only a sub-set of the unemployed.

Despite the development of the career guidance system there remain challenges to its effectiveness. These include mismatches in the labour supply and demand, particularly in the graduate labour market, and the low level of engagement by unemployed people in ALMP provision. Lack of awareness of available job opportunities and employment programmes, limits the effective functioning of the labour market.

The recent development of a Concept Paper and road map for development of work-based learning in Armenia for 2019-2025 (by the Ministry of Education, Science, Culture and Sport with support of the ETF) is expected to lead to a reduction of youth unemployment. This approach relates to the wider context of the Armenia Development Strategy 2014-2025, and the recent adoption of the 'Work, Armenia' Strategy (Republic of Armenia, 2019c) which is intended to promote competitiveness through institutional reform. This includes an aspiration to create career centres within secondary schools. The Concept Paper is focused on VET development across a range of industry sectors and includes models adopted from the German system. Its focus on VET complements the 'Professional Guidance System Development Concept'. 


\section{Conclusions and priorities for development}

There is no single best model for career guidance policy. National models are created based on the peculiarities of labour market and educational system. Provision needs to evolve in way that is sensitive to its economic, institutional and cultural context, and there are drawbacks to implementing an external model (Sultana, 2009, 2017a, b). Career guidance provision in Armenia is being developed in parallel with VET and ALMP provision, as part of a wider holistic framework. The focus is on economic growth and human capital development, with other objectives such as social justice and health (as advocated by Blustein, 2008) being less prominent. Whilst this is informed by international advice (for example, from the ETF) it is clearly an Armenian concept underpinned by adoption of active labour market measures and a rejection of passive measures. This entails risks to those economically inactive individuals whose health or personal circumstances prevent their participation in work or learning, but it is not an unusual policy position for the region (Sultana \& Watts, 2008).

During last decade the substantial reforms were implemented in career guidance and labour market policy of Armenia. ALMPs have become an important component of work towards the public policy objectives of reducing poverty, enabling access to work for the registered unemployed, and creating a high-income economy. A regional network of VET institutions was developed and staff were trained. A strategic approach to the creation of a coherent career guidance system can be situated within this policy context. In parallel, educational initiatives to develop key competencies (communication, entrepreneurship, self-awareness and self-determination) were part of the reform agenda. Armenia's policy and provision has received positive comment from international bodies, and begun to generate some evidence of its positive impact on service users.

Drawing on the recommendations of studies of career guidance in comparable nations (ETF, 2019; Sultana \& Watts, 2008; Watts \& Fretwell, 2004; Zelloth, 2012), together with the available evidence from Armenia, we suggest further development of active labour market and career guidance policy and provision is possible in these five inter-related areas: integration; access and reach; resourcing; quality and professionalisation; and evidence.

\section{Integration}

The Armenian Government has sought to provide clear leadership and to develop a coherent cross-sectoral strategy in the form of the Professional Guidance System Development Concept. Providing a structure to integrate and co-ordinate of career development activities by different stakeholders across different sectors of the education and employment systems is a recurring key recommendation of international policy commentary (e.g. Watts \& Fretwell, 2004; ICCDPP, 2019). This can be seen as a strong starting point, with effective collaboration between two government ministries. 
Nonetheless, there remains room for further development of institutions to support the effective functioning of the labour market. This means strengthening the social partnership between government agencies, employers and educational establishments, with a view to providing a qualified labour force in accordance with the current labour demand, and to promote entrepreneurship. Greater engagement of employers is a potential focus for development. One area with potential benefits would be to improve labour market forecasting mechanisms which could inform efforts to match labour supply and demand. Integrating labour market information to career development services is important, but often neglected (Bimrose, 2020).

\section{Access and reach}

A critical issue confronting public employment support and career services in Armenia at this time is their limited reach into their target populations. Further expansion of professional guidance is needed, including career counselling at all the levels of educational system (schools, vocational education and higher educational establishments), with a clearly differentiated function provided by career centres. Addressing the distinctive needs of young women who are disadvantaged as entrants to the labour market is also important. With issues of limited opportunities in rural areas, there is a need to further strengthen the network of career and training centres to better reach into regions beyond the Yerevan area. The development of online services is also highly desirable. Any new developments of this kind should integrate with the existing ALMP provision.

The extensive nature of the informal economy represents a challenge for expanding career and employment support services (Zelloth, 2012). As government provided services, they may not wish to advise on employment associated with tax avoidance, poor working conditions, worker exploitation or unsafe practices. On the other hand, it is problematic to give realistic advice about the labour market if a substantial proportion of work opportunities are not considered. Services need to find a way to engage with the informal economy to ensure their services reach out to all of the working age population, and are perceived to be credible, whilst maintaining their legal and ethical position. Providing information to workers and employers to support them in transition from the informal to the formal economy (as attempted in Georgia: Zelloth, 2009) may be a way to reconcile this tension. Reaching out may also mean accepting the importance of informal channels of career advice (e.g. within families) and providing information support to secondary client groups, such as parents.

\section{Resourcing}

The question of how to manage a substantial increase in access to career guidance and employment support services is a key challenge, and one shared by EU neighbouring countries. Affordability is a key factor, so targeting limited public resources on cost-effective and scalable methods seems advisable. This indicates that career 
education, career information, self-help services, and automated online services may be necessary solutions or possible priorities for expansion (Zelloth, 2012).

Governments have a key role in career service delivery, and often directly provide services or purchase them on behalf of their population, due to a perceived market failure in career guidance (Watts, 2008). However, governments have limited resources to draw on: they cannot do everything. They do not have a monopoly on the provision of career advice. Developing incentives to encourage the private sector and non-governmental organisations to deliver services represents an option (Watts $\&$ Fretwell, 2004). Given the relatively strong private education sector in Armenia, facilitating an environment that encourages alternative service providers may be a viable way to complement state sector provision.

\section{Quality and professionalisation}

A culture of quality assurance (QA) is becoming established in the higher education sector. The National Centre for Professional Education Quality Assurance (ANQA), is a member of the European Association for Quality Assurance in Higher Education (ENQA), and introduced a system of accreditation of higher education institutions (ANQA, 2018). More than 20 state and private universities have adopted internal QA systems. Similarly in VET colleges QA systems are being adopted with designated responsibilities for this function. Also, an eight level National Qualification Framework was adopted in 2011 and updated in 2016 (ETF, 2018b).

Within this wider culture of developing quality frameworks, there is some way to go to embed systems within the guidance sector. In their review of provision in MENA nations, Sultana and Watts (2006) highlight the importance of quality assurance and qualification standards for practitioners. These issues do have current relevance to Armenia, and there are concerns to introduce effective performance monitoring. Fortunately, there are international resources available to support the development of quality in career guidance in specific sectors (notably schools: Sultana, 2018). The career/employment counsellor role profile should combine competencies of broker, social worker, counsellor, administrator, and change agent (Vuorinen \& Kettunen, 2017).

\section{Evidence}

Some initial steps have been taken to generate evidence of career guidance effectiveness. This needs to be built on and embedded in the provision. To be sustainable and effective, services need evidence of client demand, costs, and service impact. This is necessary to demonstrate value for money, and to defend or grow the investment made by government in career services (Watts \& Fretwell, 2004).

Funding The authors received no specific funding for this work. 


\section{Compliance with ethical standards}

Conflict of interest The authors declare that they have no conflict of interest.

\section{References}

ANQA. (2018). Annual report. National Centre for Professional Education Quality Control. Retrieved from https://www.anqa.am/en/about-us/annual-reports/2018-available-in-armenian/.

Barnes, A., Bassott, B., \& Chant, A. (2011). An introduction to career learning and development 11-19: Perspectives, practice and possibilities. Routledge.

Bimrose, J. (2020). Labour market information for career development: pivotal or peripheral. In P. J. Robertson, T. Hooley, \& P. McCash (Eds.), The Oxford handbook of career development. Oxford University Press. https://doi.org/10.1093/oxfordhb/9780190069704.013.21.

Blustein, D. L. (2008). The role of work in psychological health and well-being: A conceptual, historical and public policy perspective. American Psychologist, 63, 228-240. https://doi. org/10.1037/0003-066X.63.4.228.

Cohen-Scali, V., Rossie, J., \& Nota, L. (2017). New perspectives on career counseling and guidance in Europe: Building careers in changing and diverse societies. Springer.

ETF. (2015). Migrant support measures from an employment and skills perspective (MISMES), Georgia. European Training Foundation.

ETF. (2016). Armenia: Education, training and employment developments. European Training Foundation. Retrieved from www.etf.europa.eu/web.nsf/pages/Armenia_education_training_and_emplo yment_2016.

ETF. (2018a). Armenia. Retrieved from https://www.etf.europa.eu/en/regions-and-countries/countries/ armenia.

ETF. (2018b). Armenia NQF inventory. European Training Foundation. Retrieved from https://conne ctions.etf.europa.eu/wikis/home?lang=en\#!/wiki/Wf591e43b607e_4ccf_8d94_a3256a255147/page/ Armenia\%2520-\%2520NQF\%2520Inventory.

ETF. (2018c). Armenia. Country strategy paper 2017-2020 (2018 updates). European Training Foundation. Retrieved from https://www.etf.europa.eu/sites/default/files/m/83EAA920435EEEFEC125 821F005351CE_CSP\%25202017-2020\%2520Armenia_Updates\%25202018.pdf.

ETF. (2019). Youth transition to work in Armenia. European Training Foundation. Retrieved from https:// www.etf.europa.eu/en/publications-and-resources/publications/youth-transition-work-armenia.

European Commission. (2019). Partnership implementation report on Armenia. Retrieved from https:// eeas.europa.eu/sites/eeas/files/partnership_implementation_report_armenia.pdf.

European Union. (2017). Overview of the higher education system: Armenia. Education, Audio-visual and Culture Executive Agency (EACEA). Retrieved from https://eacea.ec.europa.eu/sites/eaceasite/ files/countryfiches_armenia_2017.pdf.

European Union. (2019). European employment strategy. Retrieved from https://ec.europa.eu/social/ main.jsp?catId=101\&langId=en.

Holland, J. L. (1997). Making vocational choices: A theory of vocational personalities and work environments (3rd ed.). Psychological Assessment Resources.

ICCDPP. (2019). Communiqué of the 9th symposium on career development and public policy. International Centre for Career Development in Public Policy.

ILO. (2009). Migration and development: Armenia Country Study (Yerevan). International Labour Organisation. Retrieved from https://www.ilo.org/public/english/region/eurpro/moscow/info/publ/ migr_dev_study_en.pdf.

ILO. (2011). Decent work country profile: Armenia. International Labour Organisation. Retrieved from https://www.ilo.org/wcmsp5/groups/public/---europe/---rogeneva/---sro-moscow/documents/publi cation/wcms_307255.pdf.

ILO. (2016). School-to-work transition survey (SWTS) country brief: Armenia. International Labour Organisation. Retrieved from https://www.ilo.org/wcmsp5/groups/public/---ed_emp/documents/ publication/wcms_537747.pdf.

Kapunan, R. R. (1974). Fundamentals of guidance and counselling. Rex. 
McCarthy, J., \& Borbély-Pecze, T. B. (2020). Career guidance: living on the edge of public policy. In P. J. Robertson, T. Hooley, \& P. McCash (Eds.), The Oxford handbook of career development. Oxford University Press. https://doi.org/10.1093/oxfordhb/9780190069704.013.8.

Ministry of Labour and Social Issues of the Republic of Armenia. (undated). Home page-professional guidance and capacity building centre. Retrieved from https://www.mycareer.am.

Moreno da Fonseca, P. (2015). Guidance systems across Europe: Heritage, change and the art of becoming. British Journal of Guidance and Counselling, 43(3), 351-366. https://doi.org/10.1080/03069 885.2015.1028887.

OECD. (2010). Learning for jobs: Synthesis report of the OECD reviews of vocational education and training. Organization for Economic Co-operation and Development.

Professional Guidance and Capacity Building Centre. (2010). Educational guidance of high school students. Research on motives and values in Yerevan Schools. CRRC/Eurasia Partnership Foundation. Retrieved from https://www.mycareer.am.

Professional Guidance and Capacity Building Centre. (2016). Sociological survey on career guidance in secondary schools of the Republic of Armenia. Retrieved from https://www.mycareer.am.

Republic of Armenia. (2012). Decree on the concept of professional guidance system development. Government of the Republic of Armenia. Retrieved from https://www.irtek.am/views/act. aspx? aid=68214.

Republic of Armenia. (2013). Law on employment. Government of the Republic of Armenia. Retrieved from https://www.arlis.am/DocumentView.aspx?DocID=98887.

Republic of Armenia. (2018). Statistical yearbook of Armenia. State Statistical Committee, Government of the Republic of Armenia. Retrieved from https://armstat.am/file/doc/99510758.pdf.

Republic of Armenia. (2019a). Demographics. Government of the Republic of Armenia. Retrieved from https://www.gov.am/en/demographics/.

Republic of Armenia. (2019b). Labour market public expenditure in the Republic of Armenia. Employment State Agency. Retrieved from www.employment.am.

Republic of Armenia. (2019c). Work, Armenia. Strategy decree. Government of the Republic of Armenia. Retrieved from https://www.e-gov.am/sessions/archive/2019/12/05/.

Save the Children. (2018). Youth-focused and gender-sensitive labour market research in Armenia. Save the Children/European Union. Retrieved from https://armenia.savethechildren.net/sites/armen ia.savethechildren.net/files/library/LMR\%2520Report_Eng.pdf.

Savickas, M. (2015). Life-design counseling manual. Author. Retrieved from https://www.vocopher.com/ LifeDesign/LifeDesign.pdf.

Savickas, M., Nota, L., Rossier, J., Dauwalder, J.-P., Eduarda Duarte, M., Guicharde, J., et al. (2009). Life-designing: A paradigm for career construction in the 21-st century. Journal of Vocational Behavior, 75(3), 239-250. https://doi.org/10.1016/j.jvb.2009.04.004.

Schwab, K. (Ed.). (2019). Global competitiveness report. World Economic Forum.

Serrière, N. (2014). Labour market transitions of young women and men in Armenia. Work4Youth Publication Series, No. 21. International Labour Organisation. Retrieved from www.ilo.org/employment /areas/youth-employment/work-foryouth/publications/national-reports/WCMS_314022/lang--en/ index.htm.

Sultana, R. G. (2009). Career guidance policies: Global dynamics, local resonances. International Centre for Guidance Studies, University of Derby.

Sultana, R. G. (2017a). Anchoring career guidance in the Mediterranean? In search of southern perspectives. In R. G. Sultana (Ed.), Career guidance and livelihood planning across the Mediterranean: Challenging transitions in South Europe and the MENA region(pp. 3-15). Sense.

Sultana, R. G. (2017b). Futures for career education and guidance in the Mediterranean? In R. G. Sultana (Ed.), Career guidance and livelihood planning across the Mediterranean: Challenging transitions in South Europe and the MENA region (pp. 419-437). Sense.

Sultana, R. G. (2018). Enhancing the quality of career guidance in secondary schools: A handbook. Euroguidance.

Sultana, R. G., \& Watts, A. G. (2006). Career guidance in Public Employment Services across Europe. International Journal for Educational and Vocational Guidance, 6, 29-46. https://doi.org/10.1007/ s10775-006-0001-5.

Sultana, R. G., \& Watts, A. G. (2008). Career guidance in the Middle East and North Africa. International Journal of Educational and Vocational Guidance, 8, 19-34. https://doi.org/10.1007/s1077 5-007-9133-5. 
Super, D. L. (1980). A life-span, life-space approach to career development. Journal of Vocational Behavior, 16, 282-298.

UNESCO. (2008). Country programming document: Armenia. United Nations Educational, Scientific and Cultural Organisation. Retrieved from https://unesdoc.unesco.org/ark:/48223/pf0000158965.

Vuorinen, R., \& Kettunen, J. (2017). The European status for career service provider credentialing: professionalism in European Union (EU) guidance policies. In H. J. Yoon, B. Hutchison, M. Maze, C. Pritchard, \& A. Reiss (Eds.), International practices of career services, credentialing and training (pp. 95-111). National Career Development Association (USA). Retrieved from https://www.ncda. org/aws/NCDA/asset_manager/get_file/156343?ver=68.

Watts, A. G. (2008). Career guidance and public policy. In J. A. Athanasou \& R. van Esbroeck (Eds.), International handbook of career guidance (pp. 341-353). Springer.

Watts, A. G. (2009). The relationship of career guidance to VET. NICEC/OECD.

Watts, A. G., \& Fretwell, D. (2004). Public policies for career development: Case studies and emerging issues for designing career information and guidance systems in developing and transition economies. World Bank.

World Bank. (2012). Country data: Armenia. World Bank. Retrieved from https://data.worldbank.org/ country/Armenia.

World Bank. (2019). The World Bank in Armenia. World Bank. Retrieved from https://www.worldbank. org/en/country/armenia/overview.

Zelloth, H. (2009). In demand: Career guidance in EU neighbouring countries. European Training Foundation.

Zelloth, H. (2012). No choice- no guidance? The rising demand for career guidance in EU neighbouring countries and its potential implications for apprenticeships. In L. Deitmer, U. Hauschildt, F. Rauner, $\&$ H. Zelloth (Eds.), The architecture of innovative apprenticeship (pp. 69-87). Springer.

Publisher's Note Springer Nature remains neutral with regard to jurisdictional claims in published maps and institutional affiliations. 